\title{
Effect of Dietary Zinc Supplementation on the Productive Performances, Carcass Traits and Blood Profile of Broiler
}

\author{
Md. Firojul Islam ${ }^{1, a}$, Md. Ruknuzzaman ${ }^{2, b, *}$, Ummay Salma ${ }^{3, c}$, Abdul Gaffar Miah ${ }^{4, d}$ \\ ${ }^{I}$ Department of Animal Science and Nutrition, Hajee Mohammad Danesh Science and Technology University, Dinajpur-5200, Bangladesh \\ ${ }^{2}$ Department of Animal Production, Faculty of Veterinary and Animal Sciences, Gono Bishwabidyalay, Savar, Dhaka-1344, Bangladesh \\ ${ }^{3}$ Department of Animal Science and Nutrition, Hajee Mohammad Danesh Science and Technology University, Dinajpur-5200, Bangladesh \\ ${ }^{4}$ Department of Genetics and Animal Breeding, Hajee Mohammad Danesh Science and Technology University, Dinajpur-5200, Bangladesh
} *Corresponding author

\section{A R T I C L E I N F O A B S T R A C T}

Research Article

This study was conducted to determine the effect of zinc on the productive performances, carcass yield and blood profiles of broilers. Experiment was done for a period of 35 days with a number of 60 , day old broiler chicks. Birds were divided into four dietary treatment groups with 3 replications each having 5 birds per replication. The dietary treatment groups were; $\mathrm{T}_{0}$ (basal diet; no zinc), $\mathrm{T}_{1}$ (basal diet $+50 \mathrm{mg}$ zinc $/ \mathrm{kg}$ feed), $\mathrm{T}_{2}$ (basal diet $+100 \mathrm{mg}$ zinc $/ \mathrm{kg}$ feed), $\mathrm{T}_{3}$ (basal diet $+150 \mathrm{mg}$ zinc/kg feed). Results revealed that body weight and body weight gain were significantly increased in the zinc supplemented group compared to the control group. Higher feed intake and better FE were also observed in the zinc supplemented group than the control group and the best performance was observed in the group fed $150 \mathrm{mg}$ zinc/ $/ \mathrm{kg}$ feed $\left(\mathrm{T}_{3}\right)$. Carcass yield was significantly higher in the groups fed dietary zinc. Net profit was slightly higher in the $\mathrm{T}_{3}$ group but not significantly (P.0.05) differed with the control group. However, $\mathrm{T}_{1}$ and $\mathrm{T}_{2}$ showed less profit even than the control group. Blood profile of the experimental birds including $\mathrm{Hb}, \mathrm{PCV}$, and ESR did not significantly differ among the groups. The results indicate that the addition of zinc in the broiler diet improves productive performances, carcass yield and increases net profit without affecting the health status of broiler. So, zinc can be used as an effective and useful micronutrient to improve the

Keywords:

Zinc

Productive performances

Carcass traits

Blood profile

Broiler performances of broiler. firojbd.59@gmail.com

agfishlive.mbsk@gmail.com

\section{iD https://orcid.org/0000-0002-3849-6174|b @ruknuzzamanlitan@gmail.com (iD)https://orcid.org/0000-0001-5390-8336|d us.bd.1971@gmail.com}

http://orcid.org/0000-0001-7665-8907 https://orcid.org/0000-0001-8456-3115

\section{Introduction}

Poultry meat especially chicken meat is the most desirable animal protein and is acceptable to most of people belonging to all castes and religions. Broiler is one of the most important poultry used for fulfilling the protein demand. The broiler industry in the world developing rapidly and its success depends on how rapidly a chick attains maximum marketable weight. Broiler raisers are always interested in different approaches for attaining better growth and economic production. Unfortunately, farmers are using antibiotics with broiler feed to improve growth and feed efficiency, which adversely affects human health. As a result, each and every chicken is becoming a depot of antibiotics and other inorganic substances (Kibria et al., 2009). Due to the ban of antibiotic growth promoters in poultry diets in different countries, it is of high interest to investigate potential alternatives to maintain good growth performance of broilers.
Zinc $(\mathrm{Zn})$ is the essential trace element for growth, enzyme structure, function, appetite, normal immune function, maintenance and with particular importance for fast-growth of poultry (Naz. et al., 2016). It functions primarily as catalysts in enzyme systems within cells or as parts of enzymes. It is the also constituents of hundreds of proteins involved in intermediary metabolism, hormone secretion pathways, and immune defense (Dozier et al., 2003). At low concentrations, it serves as an essential nutrient and functions as a metal cofactor for several enzymes (Keith et al., 2000)

A few pieces of research showed that supplemental $\mathrm{Zn}$ could improve carcass traits of the animal. Organic $\mathrm{Zn}$ could increase carcass quality grade, marbling, and the fat of pelvis and heart in animals (Greene et al., 1988). Zinc consumption also increases body weight of chicken and increase in abdominal fat deposit in female chickens (Butler and Curtis, 1973). Zinc has also roles in the cell- 
mediated immune response (Fraker, 1977 and Bertuzzi, 1998) and performance (Sadoval et al., 1999), carbohydrate metabolism, and basic functions in growth performance (Mohanna, 1999).

Although zinc has a lot of feasibility to be used as a harmless trace mineral as well as a growth promoter for broiler a very few number research have been conducted to see the effect of different level of zinc on the broiler diet and there has not been any definite conclusion was drawn regarding its effect on broiler productive performances as well as on their carcass traits. Therefore, this research was conducted to investigate the effect of dietary zinc (ZisVet ${ }^{\circledR}$, zinc sulfate monohydrate) on the productive performances, carcass traits and blood profile of broiler.

\section{Materials and Methods}

\section{Experimental Site and Birds}

This experiment was conducted with 60 Cobb 500 dayold broilers for a period of 35 days (from $7^{\text {th }}$ May to $10^{\text {th }}$ June, 2020) at the poultry shed of Hajee Mohammad Danesh Science \& Technology University, Dinajpur, Bangladesh. The aim was to investigate the effect of supplying the different levels of zinc with the feed to improve the production performances of broilers.

\section{Experimental Preparation}

The zinc solution used in this experiment was purchased from local market named Zinc-Vet ${ }^{\circledR}(1 \mathrm{ml}$ solution contain $2 \mathrm{mg}$ zinc sulfate monohydrate USP) which was manufactured and marketed by Navana Bangladesh, Animal health division (a reputed veterinary drugs company), Bangladesh. For the free of cost support, experimental solution was collected from Navana Bangladesh, Animal health division.

\section{Experimental Layout}

The day-old broilers were randomly assigned into 4 dietary treatment groups having 3 replications in each treatment. The treatments were $0,50,100$, and $150 \mathrm{mg}$ zinc in each $\mathrm{kg}$ of feed. There were 5 broilers in each replication. The layout of the experiment is presented in Table 1.

\section{General Management}

Preparation of the experimental house and equipment

The experimental house was divided into 4 parts for four dietary treatment groups and each part was subdivided into three parts to facilitate the accommodation of 5 birds in each sub-group. After15 days the room was disinfected with PPM solution. The experimental room was thoroughly brushed, swiped, and properly washed by water after that bleaching powder @ 1kg/500sq.ft was spread over the floor and it was kept 24 hours without any further attention. The bleaching powder was cleaned by using forced tap water. After that, the room was disinfected by TH4+ solution (Manufactured by Sogeval, France, Marketed by-Century Agro Ltd, Bangladesh). Feeders, waterer, buckets, and all other necessary equipment were also properly, washed and disinfected by TH4+ solution. Subsequently dried them and left empty for a week before the arrival of chicks. Fresh dried sow dust was used as litter at a depth of $2 \mathrm{~cm}$. All birds were reared under thesame care and management.

\section{Feed management}

For the first seven days, the feed was given in the paper and then in small trays. After that feed was supplied in the round feeder. Zinc solution was at first taken by the measuring syringe then mixed with the pellet feed. After mixing the experimental zinc solution with the feed in the required amount, the feed was supplied to the different groups of birds according to their age. Nutrient requirement of the study birds was calculated according to NRC, 1994. Feed was purchased from the Nourish feed company. The feed contains the following nutrients.

Table 1. Layout showing the distribution of broilers to treatments and replications

\begin{tabular}{|c|c|c|c|c|c|}
\hline \multirow{2}{*}{ Replication } & \multicolumn{4}{|c|}{ Zinc level (mg/kg feed) } & \multirow{2}{*}{ Total } \\
\hline & $0\left(\mathrm{~T}_{0}\right)$ & $50\left(\mathrm{~T}_{1}\right)$ & $100\left(\mathrm{~T}_{2}\right)$ & $150\left(\mathrm{~T}_{3}\right)$ & \\
\hline 1 & 5 & 5 & 5 & 5 & 20 \\
\hline 2 & 5 & 5 & 5 & 5 & 20 \\
\hline 3 & 5 & 5 & 5 & 5 & 20 \\
\hline Total & 15 & 15 & 15 & 15 & 60 \\
\hline
\end{tabular}

Table 2. Nutrient analysis of the supplied feed.

\begin{tabular}{l|l}
\hline \multicolumn{1}{c|}{ Ingredient } & \multicolumn{1}{c}{ Amount } \\
\hline Moisture & $12 \%$ (maximum) \\
Protein & $20 \%$ (minimum) \\
Fiber & $5 \%$ (maximum) \\
Calcium & $0.95 \%$ (minimum) \\
Phosphorus & $0.45 \%$ (minimum) \\
Lysin & $0.45 \%$ (minimum) \\
Methionine & $1.05 \%$ (minimum) \\
Metabolic Energy & $3000 \mathrm{kcal} / \mathrm{kg}$ (minimum) \\
\hline
\end{tabular}

Water management

All birds were supplied all-time with ad libitum clean, cool natural drinking water. Water was supplied through the waterer.

Rearing system

Experimental birds were reared under the bamboo made floor which was 2 feet above the ground. Feces were passed through the space between the bamboo strides.

Lighting

The birds were exposed to a continuous lighting of 23 hours and 1 hour dark in 24 hours. Supplementary light at night was provided by an electric bulb at a height of 2.8 meters to provide the necessary lighting.

\section{Brooding management}

At the beginning of the first week of age brooding temperature was kept $32^{\circ} \mathrm{C}$ and decreased gradually in subsequent weeks @ $2.5^{\circ} \mathrm{C} /$ week until the birds were adjusted to environmental temperature. The broilers were exposed to 23 hours of continuous light and a dark period of 1 hour per day throughout the experimental period. Fresh and dried rice husk was used as a litter at a depth of about $3 \mathrm{~cm}$. The floor space given to each broiler was $960 \mathrm{~cm}^{2}$. During 35 days of the experimental period, the following parameters were recorded and calculated.

Hygiene and sanitation

During the experimental period, proper sanitary measures were taken. Footbath were placed in front of the farm. No visitors were allowed on the farm. Feed wastes and feces were regularly cleaned. 


\section{Recordkeeping}

All events of the experiment like the amount of feed given, feed leftover, body weight etc., are regularly taken and properly maintained in the record book.

\section{Measurements and Methods of Interpreting Results}

Different parameters of the experimental bird were calculated by the following way

\section{Live body weight ( $L B W)$}

Birds were individually weighed to the nearest gram in the early morning before providing any food and water at the initial weight and weekly during the experimental period.

\section{Live weight gain of birds}

It was calculated by using the following formula

$$
\mathrm{LWGR}_{\mathrm{X}}=\mathrm{LWR}_{\mathrm{X}}-\mathrm{LWD}_{0}
$$

Where:

$\mathrm{LWD}_{0}=$ Initial weight of the birds at the time of the start of the experiment.

$\mathrm{LWD}_{\mathrm{x}}=$ Final weight of the birds at the $\mathrm{x}$ time period.

( $\mathrm{x}=$ Specific weeks when body weight is calculated)

\section{Feed Intake}

Weekly feed intake was taken by deducting the feed

\section{Feed efficiency (FE)}

Feed efficiency was calculated using the following formula (according to Ensmingar, 1980):

$$
\mathrm{FE}=\frac{\text { Total weight gain }(\mathrm{g}) / \text { birds during a certain period }}{\text { Feed Consumption }(\mathrm{g}) / \text { birds during the same period }}
$$

\section{Meat yield characteristics}

At the end of the experimental period, one broiler weighing an average of the pen weight from each replication was selected, slaughtered, and dissected. The broilers were dissected and the meat was separated from carcass following the procedure of Jones (1984). Records were kept on the weight of dress yield, breast meat, thigh meat, drumstick meat, wing meat, abdominal fat, liver, heart, gizzard, spleen weight, the thigh bone, drumstick bone, wing bone, skin, head, neck, shank, feather and blood.

\section{Blood parameters}

PCV is determined by using the method and formula described by Lamberg and Rothstein (1977).

$$
\mathrm{PCV} \%=\frac{\text { Height of the red cell volume }(\mathrm{cm})}{\text { Height of the total blood }(\mathrm{cm})} \times 100
$$

HB \% was determined by using Helligehemo meter method as described by Lamberg and Rothstein (1977). ESR was determined by using Wintrobe hematocrit tube.

\section{Statistical Analyses}

The birds were assigned to different experimental groups under Completely Randomized Design (CRD). The data were analyzed by the Statistical Package for Social Science (SPSS) program. The data were expressed as the the Mean \pm SEM and significance level was calculated under $5 \%$ level of significance.

\section{Results}

\section{Live Weight}

The live weight of birds during the experimental period is presented in Table 3. The present experiment was started with day-old chicks with an average live weight of $45 \pm 0.19$ g. On the $7^{\text {th }}$ day, live weight of birds was not significantly differed $(\mathrm{P}>0.05)$ among the groups but it was significantly $(\mathrm{P}<0.05)$ differed on the $14^{\text {th }}, 21^{\text {st }}$, and $28^{\text {th }}$ day of the experimental period where higher live weight was observed in the bird fed $150 \mathrm{mg}$ zinc/ $\mathrm{kg}$ of feed than the birds of the control group ( $0 \mathrm{mg}$ Zinc/ $\mathrm{kg}$ feed). Although birds fed 50 and $100 \mathrm{mg}$ Zinc/kg feed showed higher live weight gain but not significantly differed with the control group. At the end of the experiment significantly higher live weight was observed in the birds fed 100 and $150 \mathrm{mg}$ Zinc/kg feed (1494.3 and $1758.53 \mathrm{~g}$, respectively) than the control group (1376.8 g).

\section{Live Weight Gain}

The weight gain of the experimental birds at the day of 35 is shown in Figure 1. It was observed that weight gain at the day of 35 was significantly $(\mathrm{P}<0.05)$ higher in the birds fed 100 and $150 \mathrm{mg}$ Zinc/kg feed (1249.3g and $1513.53 \mathrm{~g}$, respectively) than the control group $\mathrm{T}_{0}(1131.8 \mathrm{~g})$. However, higher weight gain was also observed in the birds fed $50 \mathrm{~g}$ zinc/ $\mathrm{kg}$ feed (1175.3 g) but was not significantly different $(\mathrm{P}>0.05)$ than the control group (1131.8 $\mathrm{g}$ )

\section{Feed Consumption}

Feed consumption of birds during the experimental period is shown in Figure 2. It was observed that feed consumption was significantly $(\mathrm{P}<0.05)$ higher in the birds fed $100 \mathrm{mg}$ Zinc/kg feed (2717 g/broiler) and $150 \mathrm{mg}$ Zinc/kg feed (2816 g/broiler) than the control group $\mathrm{T}_{0}$ $(2512 \mathrm{~g})$. However, higher feed consumption was also observed in the birds fed $50 \mathrm{~g}$ zinc/ $\mathrm{kg}$ feed ( $2634 \mathrm{~g} / \mathrm{broiler})$ but was not significantly differed $(\mathrm{P}>0.05)$ than the control group ( $2512 \mathrm{~g} / \mathrm{broiler})$.

\section{Feed Efficiency (FE)}

Feed efficiency (FE) of birds during the experimental period is presented in Figure 3. It was observed that FE was significantly $(\mathrm{P}<0.05)$ differed between the birds fed $150 \mathrm{mg}$ Zinc/ kg feed (1.79) and control group $\mathrm{T}_{0}$ (2.13). Birds fed, 50 $\mathrm{mg}$ Zinc/kg feed showed slightly higher FE (2.15) than the control group (2.13) but this difference is not statistically significant $(\mathrm{P}>0.05)$. However, birds fed $150 \mathrm{mg}$ Zinc $/ \mathrm{kg}$ feed also showed lower FE (2.09) but was not significantly ( $\mathrm{P}>0.05)$ differed that of the control group (2.15).

\section{Carcass Yield}

Weight of different internal organs such as heart, gizzard, liver, spleen, pancreas of the birds of $T_{0}, T_{1}$ and $T_{2}$ are shown in Table 4. Statistical analysis of the data did not show any difference between the relative organ's weight of the birds of different feeding groups using feed with or without supplementation of Zinc.

For evaluating carcass yield characteristics dressing yield, breast meat, thigh meat, drumstick meat, drumstick bone, wing meat, abdominal fat, gizzard, head, heart, liver, neck wt., wing bone, blood, thigh bone, spleen and skin were taken as variables. 
Table 3. Live weight of birds fed different level of Zinc

\begin{tabular}{l|ccccc}
\hline \multirow{2}{*}{ Live weight $(\mathrm{g})$} & \multicolumn{4}{|c}{ Dietary Treatments } & \multicolumn{2}{c}{$\begin{array}{c}\text { Level of } \\
\text { Significance }\end{array}$} \\
\cline { 2 - 5 } & $\mathrm{T}_{0}$ & $\mathrm{~T}_{1}$ & $\mathrm{~T}_{2}$ & $\mathrm{~T}_{3}$ & $\mathrm{NS}$ \\
0 day (day old) & $45 \pm 0.12$ & $44.8 \pm 0.18$ & $45.1 \pm 0.21$ & $45.3 \pm 0.16$ & $\mathrm{NS}$ \\
$7^{\text {th }}$ day & $203^{\mathrm{a}} \pm 1.42$ & $202.5 \pm 1.91^{\mathrm{a}}$ & $202 \pm 2.31^{\mathrm{a}}$ & $204 \pm 2.57^{\mathrm{a}}$ & $*$ \\
$14^{\text {th }}$ day & $385.8 \pm 4.54^{\mathrm{a}}$ & $467.4 \pm 3.48^{\mathrm{b}}$ & $442.7 \pm 2.21^{\mathrm{ab}}$ & $489.4 \pm 2.89^{\mathrm{b}}$ & $*$ \\
$21^{\text {st }}$ day & $667.8 \pm 6.87^{\mathrm{a}}$ & $646.8 \pm 4.21^{\mathrm{a}}$ & $691.7 \pm 4.15^{\mathrm{a}}$ & $901.13^{ \pm} 0.4^{\mathrm{b}}$ & $*$ \\
$28^{\text {th }}$ day & $1078.3 \pm 6.18^{\mathrm{a}}$ & $1163.6 \pm 7.4^{\mathrm{a}}$ & $1176.5 \pm 1.63^{\mathrm{a}}$ & $1439.3 \pm 5.35^{\mathrm{b}}$ & $*$ \\
$35^{\text {th }}$ day & $1376.8 \pm 11.42^{\mathrm{a}}$ & $1320.3 \pm 7.23^{\mathrm{ab}}$ & $1494.3 \pm 9.14^{\mathrm{b}}$ & $1758.53 \pm 6.16^{\mathrm{c}}$ & $* *$ \\
\hline
\end{tabular}

The above values represent the Mean \pm standard an error (SE) of the live weight of the broiler in different weeks of the experimental period. The Mean values with the same superscripts within the same row are statistically non-significant $(\mathrm{P}>0.05)$ and The Mean values with the different superscripts within the same row are statistically significant $(\mathrm{P}<0.05),{ }^{*}$ Here, $\mathrm{T}_{0}=0 \mathrm{mg} \mathrm{Zinc} / \mathrm{kg}$ of feed (Control group), $\mathrm{T}_{1}=50 \mathrm{mg} \mathrm{Zinc} / \mathrm{kg}$ of feed, $\mathrm{T}_{2}=100 \mathrm{mg}$ Zinc/ $\mathrm{kg}$ of feed and $\mathrm{T}_{3}=150 \mathrm{mg}$ Zinc/ $\mathrm{kg}$ of feed.

Table 4. Carcass characteristics of broiler birds fed different level of Zinc

\begin{tabular}{|c|c|c|c|c|c|}
\hline \multirow[b]{2}{*}{ Parameter $(\%)$} & \multirow{2}{*}{$\begin{array}{c}\text { Control } \\
\mathrm{T}_{0}(\mathrm{n}=5) \mathrm{The} \\
\text { Mean } \pm \text { SE }\end{array}$} & \multicolumn{3}{|c|}{ Dietary treatment groups } & \multirow[b]{2}{*}{$\begin{array}{c}\text { Level of } \\
\text { Significance }\end{array}$} \\
\hline & & $\begin{array}{c}T_{1}(n=5) \text { The } \\
\text { Mean } \pm \text { SE }\end{array}$ & $\begin{array}{c}\mathrm{T}_{2}(\mathrm{n}=5) \text { The } \\
\text { Mean } \pm \text { SE }\end{array}$ & $\mathrm{T}_{3}(\mathrm{n}=5)$ & \\
\hline Dressing yield & $55.90^{\mathrm{a}} \pm 1.73$ & $57.45^{\mathrm{ab}} \pm 1.35$ & $58.10^{\mathrm{ab}} \pm 1.19$ & $61.75^{\mathrm{b}} \pm 1.41$ & $*$ \\
\hline Breast meat & $14.62 \pm 1.73$ & $14.81 \pm 1.73$ & $14.67 \pm 1.73$ & $14.03 \pm 1.73$ & NS \\
\hline Thigh meat & $8.15^{ \pm} 0.73^{\mathrm{a}}$ & $8.25 \pm 0.13^{\mathrm{a}}$ & $8.85 \pm 0.81^{\mathrm{ab}}$ & $9.33 \pm 0.95^{\mathrm{b}}$ & $*$ \\
\hline Drumstick meat & $5.27 \pm 0.31^{\mathrm{a}}$ & $5.78^{\mathrm{ab}} \pm 0.41$ & $5.91^{\mathrm{ab}} \pm 0.38$ & $6.43^{\mathrm{b}} \pm 0.41$ & $*$ \\
\hline Drumstick bone & $1.81 \pm 1.05$ & $1.93 \pm 0.10$ & $1.87 \pm 0.12$ & $1.91 \pm 0.09$ & NS \\
\hline Wing meat & $3.22 \pm 0.21$ & $3.24 \pm 0.38$ & $3.72 \pm 0.37$ & $3.79 \pm 0.12$ & NS \\
\hline Abdominal fat & $1.21 \pm 0.11$ & $1.19 \pm 0.05$ & $1.75 \pm 0.03$ & $1.82 \pm 0.02$ & NS \\
\hline Gizzard & $1.44 \pm 0.02$ & $1.46 \pm 0.05$ & $1.46 \pm 0.11$ & $1.51 \pm 0.15$ & NS \\
\hline Head & $2.49 \pm 0.16$ & $2.43 \pm 0.21$ & $2.48 \pm 0.15$ & $2.46 \pm 0.17$ & NS \\
\hline Heart & $0.47 \pm 0.005$ & $0.46 \pm 0.02$ & $0.47 \pm 0.04$ & $0.49 \pm 0.09$ & NS \\
\hline Liver & $2.20 \pm 0.12$ & $2.24 \pm 0.15$ & $2.18 \pm 0.13$ & $2.19 \pm 0.08$ & NS \\
\hline Neck wt. & $1.74 \pm 0.03$ & $1.51 \pm 0.05$ & $1.86 \pm 0.07$ & $1.82 \pm 0.07$ & NS \\
\hline Wing bone & $2.09 \pm 0.11$ & $2.25 \pm 0.16$ & $2.16 \pm 0.12$ & $2.31 \pm 0.17$ & NS \\
\hline Blood & $4.07 \pm 0.09$ & $4.09 \pm 0.17$ & $4.36 \pm 0.12$ & $4.65 \pm 0.18$ & NS \\
\hline Thigh bone & $1.27 \pm 0.11$ & $1.24 \pm 0.07$ & $1.38 \pm 0.09$ & $1.42 \pm 0.11$ & NS \\
\hline Spleen & $0.15 \pm 0.002$ & $0.14 \pm 0.004$ & $0.12 \pm 0.007$ & $0.15 \pm 0.002$ & NS \\
\hline Skin & $8.21 \pm 0.53$ & $8.19 \pm 0.36$ & $7.96 \pm 0.75$ & $8.39 \pm 0.81$ & NS \\
\hline
\end{tabular}

The above values represent the the Mean \pm standard an error (SE) of the live weight of broiler in different weeks of the experimental period. The Mean values with the same superscripts within the same row are statistically non-significant $(\mathrm{P}>0.05)$ and The Mean values with the different superscripts within the same row are statistically significant $(\mathrm{P}<0.05)$, *Here, $\mathrm{T}_{0}=0 \mathrm{mg}$ Zinc/ $\mathrm{kg}$ of feed (Control group), $\mathrm{T}_{1}=50 \mathrm{mg}$ Zinc/ $\mathrm{kg}$ of feed, $\mathrm{T}_{2}=100 \mathrm{mg}$ Zinc/ $\mathrm{kg}$ of feed and $\mathrm{T}_{3}=150 \mathrm{mg}$ Zinc/ $\mathrm{kg}$ of feed.

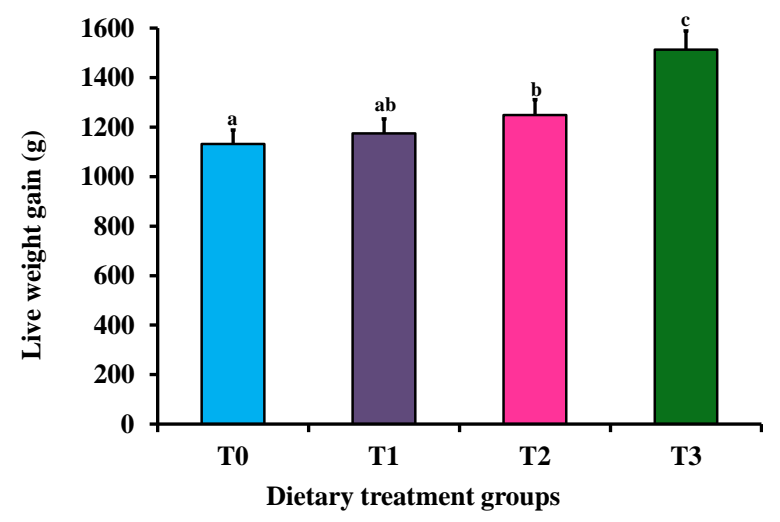

Figure 1. Live weight gain (g) of broiler birds fed different levels of Zinc

$\left(\mathrm{T}_{0}=0 \mathrm{mg}\right.$ Zinc $/ \mathrm{kg}$ of feed (Control group), $\mathrm{T}_{1}=50 \mathrm{mg}$ Zinc $/ \mathrm{kg}$ of $\quad\left(\mathrm{T}_{0}=0 \mathrm{mg}\right.$ Zinc $/ \mathrm{kg}$ of feed (Control group), $\mathrm{T}_{1}=50 \mathrm{mg}$ Zinc $/ \mathrm{kg}$ of feed, $\mathrm{T}_{2}$ feed, $\mathrm{T}_{2}=100 \mathrm{mg}$ Zinc $/ \mathrm{kg}$ of feed and $\mathrm{T}_{3}=150 \mathrm{mg}$ Zinc $/ \mathrm{kg}$ of feed). Each $=100 \mathrm{mg}$ Zinc $/ \mathrm{kg}$ of feed and $\mathrm{T}_{3}=150 \mathrm{mg}$ Zinc $/ \mathrm{kg}$ of feed). Each bar bar with an an error bar represents the The Mean \pm SEM value. Differences were significant $(\mathrm{P}<0.01)$ among the groups.

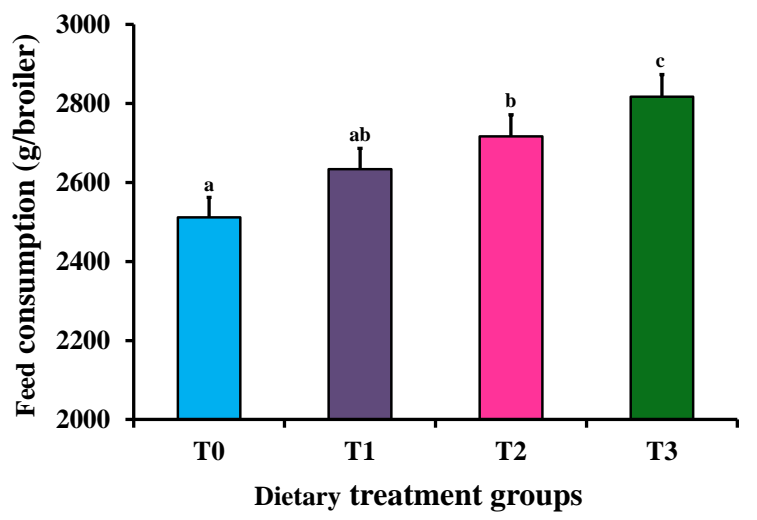

Figure 2. Feed consumption (g/bird) of broiler fed different levels of Zinc

with an error bar represents The The Mean \pm SEM value. Differences were significant $(\mathrm{P}<0.01)$ among the groups. 
It was observed that except dressing yield, thigh meat and drumstick meat all other variables are not significantly differed among the groups. Dressing yield was highest at birds fed $150 \mathrm{mg}$ zinc/ $\mathrm{kg}$ feed while it was 55.90, 57.45 and $58.10 \mathrm{~g}$ in $\mathrm{T}_{0}, \mathrm{~T}_{1}$ and $\mathrm{T}_{3}$ group, respectively. Thigh meat weight was also significantly higher in the birds fed $150 \mathrm{mg}$ zinc/ $\mathrm{kg}$ feed while it was $8.15,8.25$ and $8.85 \mathrm{~g}$ in $\mathrm{T}_{0}, \mathrm{~T}_{1}$ and $\mathrm{T}_{2}$ group, respectively. Drumstick meat was also significantly higher in weight in the birds fed $150 \mathrm{mg}$ zinc/ $\mathrm{kg}$ feed $(6.43 \mathrm{~g})$. Thigh meat contains more protein less fat, has less tendon, ligaments, myoglobin and blood vessels than of dark meat. As a result, the digestibility of thigh meat is higher than other meat. The demand is higher for thigh meat than the dark meat.

Thus, thigh meat is one of the valuable parts of the broiler. So, the differences in the thigh and drumstick meat yield are manically important.

\section{Blood Profile}

Hematological parameters of the experimental birds were shown in Table-5. It was found that hemoglobin $(\mathrm{g} / \mathrm{dl})$ was not significantly differed $(\mathrm{P}>0.05)$ among the different groups of broiler birds $(6.50,6.65,6.80$ and $6.91 \mathrm{~g} / \mathrm{dl}$ respectively in $\mathrm{T}_{0}, \mathrm{~T}_{1}, \mathrm{~T}_{2}$ and $\mathrm{T}_{3}$ groups, respectively). Packed cell volume (PCV) was 16.80, 17.10, 17.40 and $17.38 \%$ in $\mathrm{T}_{0}, \mathrm{~T}_{1}, \mathrm{~T}_{2}$ and $\mathrm{T}_{3}$ groups, respectively which was not significantly $(\mathrm{P}>0.05)$ differed among the groups. Erythrocyte sedimentation rate (ESR) was not significantly differed $(\mathrm{P}>0.05)$ among the treatment and control groups and it was 6.67, 6.45, 6.45, 6.65 and $6.67 \mathrm{~mm}$ in $\mathrm{T}_{0}, \mathrm{~T}_{1}$ and $\mathrm{T}_{2}$ group, respectively.

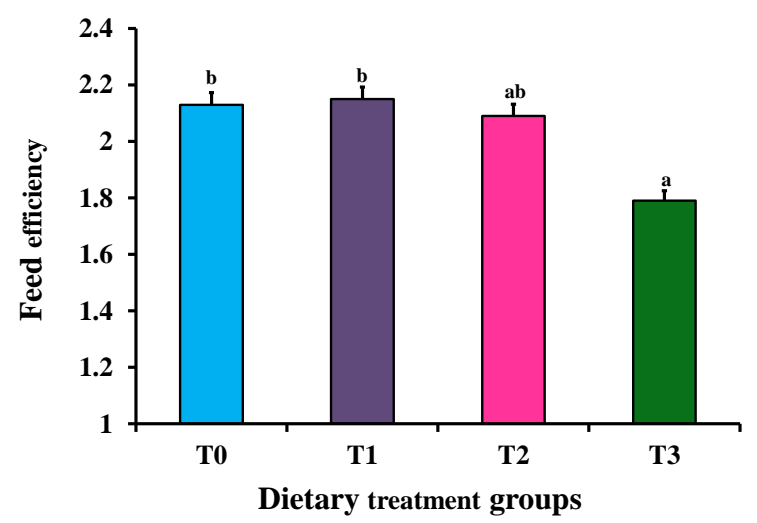

Figure 3. Feed efficiency of broiler birds fed different levels zinc

( $\mathrm{T}_{0}=0 \mathrm{mg}$ Zinc $/ \mathrm{kg}$ of feed (Control group), $\mathrm{T}_{1}=50 \mathrm{mg} \mathrm{Zinc} / \mathrm{kg}$ of feed, $\mathrm{T}_{2}=100 \mathrm{mg} \mathrm{Zinc} / \mathrm{kg}$ of feed and $\mathrm{T}_{3}=150 \mathrm{mg}$ Zinc $/ \mathrm{kg}$ of feed). Each bar with an error bar represents the Mean \pm SEM value. Differences were significant $(\mathrm{P}<0.05)$ among the groups.

\section{Cost-Benefit Analysis of Production}

The average rearing costs, live weight and net profit of birds are shown in Table 6 . The average rearing costs of broiler kept under different treatment groups were not significantly $(\mathrm{P}>0.05)$ differed among the groups. But the feed cost was slightly higher in treated groups due to the high feed intake in the treated groups and it was $103 \mathrm{Tk}$, $108 \mathrm{Tk}$. and $111.39 \mathrm{Tk}$. and 115.51 , respectively in $\mathrm{T}_{0}, \mathrm{~T}_{1}$, $\mathrm{T}_{2}$ and $\mathrm{T}_{3}$ group respectively. The total rearing cost of broiler was significantly higher $(\mathrm{P}<0.05)$ in the birds fed 100 and $150 \mathrm{mg} \mathrm{Zinc/kg}$ of feed (204.3 and 223.5 Tk., respectively) than in the control group (166 Tk.). Although birds fed $50 \mathrm{mg}$ Zinc/kg of feed had a higher rearing cost (186.0 Tk.) but did not significantly differed than the control group. This difference between the groups was due to the variation of feed intake and cost of zinc. As live weight of broiler significantly differed among the groups total sale price/broiler was also significantly differed between the birds fed $150 \mathrm{mg}$ Zinc/kg feed (270 Tk.) and birds of the control group (207 Tk./broiler). Sale price/broiler in $\mathrm{T}_{1}\left(210 \mathrm{Tk}\right.$. /broiler) and $\mathrm{T}_{2}$ group $(225 \mathrm{Tk}$. / broiler) was slightly higher but not significantly different from the control group. Net profit/broiler) highest in the birds fed $150 \mathrm{mg}$ Zinc/kg feed (46.48 Tk. / broiler) was not significantly $(\mathrm{P}>0.05)$ differed than the control group (40.99 Tk.).

However, birds fed 50 and $100 \mathrm{mg} \mathrm{Zinc} / \mathrm{kg}$ of feed showed a significantly lower profits (23.98 and $20.60 \mathrm{Tk}$., respectively). This was due to the comparatively lower weight gain of these groups birds despite of high feed and zinc intake.

Table 5. Hematological parameters of broiler fed different level of dietary zinc

\begin{tabular}{l|ccccc}
\hline \multirow{2}{*}{ Blood Parameters } & \multicolumn{4}{|c}{ Dietary treatment groups* } & Level of \\
\cline { 2 - 5 } & $\mathrm{T}_{0}$ & $\mathrm{~T}_{1}$ & $\mathrm{~T}_{2}$ & $\mathrm{~T}_{3}$ & Significance \\
\hline Hemoglobin $(\mathrm{g} / \mathrm{dl})$ & $6.50 \pm 0.12$ & $6.65 \pm 0.06$ & $6.80 \pm 0.07$ & $6.91 \pm 0.07$ & $\mathrm{NS}$ \\
PCV (\%) & $16.80 \pm 0.67$ & $17.10 \pm 0.49$ & $17.40 \pm 0.50$ & $17.38 \pm 0.30$ & $\mathrm{NS}$ \\
ESR (mm in $1^{\text {st }}$ hour) & $6.67 \pm 0.76$ & $6.45 \pm 0.68$ & $6.65 \pm 0.63$ & $6.73 \pm 0.87$ & $\mathrm{NS}$ \\
\hline
\end{tabular}

The above values represent the the Mean \pm standard an error (SE) of the live weight of broiler in different weeks of the experimental period. The Mean values with the same superscripts within the same heading are statistically non-significant $(\mathrm{P}>0.05)$ and The Mean values with the different superscripts within the same headings are statistically significant $(\mathrm{P}<0.05)$, Here, $\mathrm{T}_{0}=0 \mathrm{mg} \mathrm{Zinc} / \mathrm{kg}$ of feed $($ Control group $), \mathrm{T}_{1}=50 \mathrm{mg} \mathrm{Zinc} / \mathrm{kg}$ of feed, $\mathrm{T}_{2}=100$ $\mathrm{mg} \mathrm{Zinc} / \mathrm{kg}$ of feed and $\mathrm{T}_{3}=150 \mathrm{mg} \mathrm{Zinc} / \mathrm{kg}$ of feed. 
Table 6. Cost-benefit analysis of broiler production among different groups.

\begin{tabular}{l|ccccc}
\hline \multicolumn{1}{c|}{ Description } & $\begin{array}{c}\mathrm{T} 0 \\
(\text { Control })\end{array}$ & $\begin{array}{c}\mathrm{T}_{1} \\
(50 \mathrm{~g} / \mathrm{kg} \text { Zinc })\end{array}$ & $\begin{array}{c}\mathrm{T}_{2} \\
(100 \mathrm{~g} / \mathrm{kg} \text { Zinc })\end{array}$ & $\begin{array}{c}\mathrm{T}_{2} \\
(150 \mathrm{~g} / \mathrm{kg} \text { Zinc })\end{array}$ & $\begin{array}{c}\text { Level of } \\
\text { significant }\end{array}$ \\
\hline Cost/chick (Taka) & 55 & 55 & 55 & 55 & $\mathrm{NS}$ \\
Average feed consumed (g)/chicks & $2512 \pm 17.1^{\mathrm{a}}$ & $2634 \pm 21.5^{\mathrm{ab}}$ & $2717 \pm 35.3^{\mathrm{b}}$ & $2817 \pm 19.4^{\mathrm{c}}$ & $* *$ \\
Feed price/Kg (Tk.) & 41 & 41 & 41 & 41 & - \\
Cost of zinc (Tk.) & 0 & 15 & 30 & 45 & $*$ \\
Feed cost (Tk.) & 103.00 & 108.01 & 111.39 & 115.51 & $\mathrm{NS}$ \\
Miscellaneous (Tk.) & 8 & 8 & 8 & 8 & - \\
Total cost/broiler (Tk.) & $166.0 \pm 5.1^{\mathrm{a}}$ & $186.0 \pm 4.3^{\mathrm{ab}}$ & $204.3 \pm 3.8^{\mathrm{b}}$ & $223.5 \pm 7.9^{\mathrm{c}}$ & $* *$ \\
Average live weight (Kg) & $1.38 \pm 0.011^{\mathrm{a}}$ & $1.4 \pm 0.072^{\mathrm{ab}}$ & $1.5 \pm 0.0914^{\mathrm{b}}$ & $1.8 \pm 0.0616^{\mathrm{c}}$ & $* *$ \\
Sale price/Kg live wt. (Taka.) & 150 & 150 & 150 & 150 & - \\
Sale price/broiler (Taka) & $207 \pm 5.4^{\mathrm{a}}$ & $210 \pm 3.1^{\mathrm{a}}$ & $225 \pm 2.0^{\mathrm{ab}}$ & $270 \pm 1.9^{\mathrm{b}}$ & $* *$ \\
Net profit/broiler (Taka.) & $40.99 \pm 5.1^{\mathrm{b}}$ & $23.98 \pm 5.1^{\mathrm{a}}$ & $20.60 \pm 5.1^{\mathrm{a}}$ & $46.48 \pm 5.1^{\mathrm{b}}$ & $*$ \\
\hline
\end{tabular}

The above values represent the the Mean \pm standard an error (SE) of the live weight of broiler in different weeks of the experimental period. The Mean values with the same superscripts within the same row are statistically non-significant $(\mathrm{P}>0.05)$ and The Mean values with the different superscripts within the same row are statistically significant $(\mathrm{P}<0.05), *=(\mathrm{P}<0.05)$ and $* *=(\mathrm{P}<0.01) . * \mathrm{Here}^{*} \mathrm{~T}_{0}=0 \mathrm{~g} \mathrm{Zinc} / \mathrm{kg}$ of feed $(\mathrm{Control}$ group $), \mathrm{T}_{1}=50 \mathrm{~g} \mathrm{Zinc} /$ $\mathrm{kg}$ of feed, $\mathrm{T}_{2}=100 \mathrm{~g}$ Zinc $/ \mathrm{kg}$ of feed and $\mathrm{T}_{3}=150 \mathrm{~g} \mathrm{Zinc} / \mathrm{kg}$ of feed.

\section{Discussion}

The present experiment showed that feeding broiler birds with zinc increased the live weight and live weight gain in comparison to the control group. This significant difference in live weight and live weight gain is might be due to the association of zinc in protein metabolism of broiler birds. It was maybe due to the critical importance of Zinc in maintaining the structure of metalloproteins such as insulin and growth hormone. Zinc deficiency primarily affects protein metabolism in fast-growing animals (Swinkels et al., 1994). Results from the growth performance of this study showed that supplemental $\mathrm{Zn}$ promoted the growth of broilers. Present findings support the findings of Ezzati et al. (2013) in which they found supplementation of $125 \mathrm{ppm}$ zinc had a significantly higher live weight (2734 g) than the un-supplemented group (2680 g). Liu et al. (2012) also found a significant effect in live weight of broiler birds by supplying a different level of zinc. Midilli et al. (2014) found increasing live weight, while they supplied inorganic and organic forms of zinc alone or in combination with microbial phytase. Abhishek et al. (2016) reported a significant effect on the increase in live weight in groups fed with $80 \mathrm{mg} / \mathrm{kg}$ of zinc from 21 45 days of age, the author found the lowest live weight of birds in the control group than the other 4 treatment groups which prove that zinc was essential for growth. Bartlett and Smith (1998) found that a significant increase in live weight of zinc fed broiler occurs than the control group (1576 g vs $1387 \mathrm{~g}$ avg. live weight in birds fed adequate and no zinc). Feed efficiency of birds also better in zinctreated birds which supports the findings of HosseiniMansoub et al. (2010) in which they found zincsupplemented birds had a lower FE than the unsupplemented zinc group. The present findings do not support the findings of Ezzati et al. (2013) in which they found supplementation of 125ppm zinc had a FE 2.15 which was not significantly lower than the unsupplemented zinc group FE (2.15). Huang et al. (2007) also found the highest FE when zinc was added at the level of $20 \mathrm{mg} / \mathrm{kg}$ in the diet. Another form of zinc is reported to beneficial for broilers is zinc-methionine which improves the feed efficiency significantly rather than zinc oxide (Sanford and Kawchumnong, 1972). However, feed intake did not differ among different treated and control groups.
Ezzati et al. (2013) also found the same result, in which they found supplementation of $125 \mathrm{ppm}$ zinc had a significantly higher feed intake $(6030 \mathrm{~g})$ than the unsupplemented group (5878 g). It is very difficult to explain the mechanism of an increasing trend of the thigh and drumstick meat yield for groups receiving zinc in the feed. Most probably this effect was due to the comparative increase in the live weight of broiler birds fed zinc. Present findings support the findings of Ezzati et al. (2013) in which they also found a significantly higher carcass yield in zinc supplemented birds than the un-supplemented group. But Liu et al. (2012) had not found any significant effect in carcass yield characteristics of broiler birds by supplying a different level of zinc.

Analysis of blood parameters revealed that zinc has no negative effect on the blood profile of broiler birds that the Means broiler birds were physically sound and healthy during the experimental period and experimented zinc supplementation was safe for the broiler birds. The value of the birds of different groups does not differ significantly among the groups and it was within the normal range. In economic perspective, supplementation of zinc improved productive performances of broilers. So, it is more profitable and economic.

In the end, it can be sum up that, zinc can be safely and beneficially used in broiler diets to improve their productive performances, carcass yield and economic benefit. Present research findings may be useful for the small and large scale poultry farmers to earn more profit through improving broiler performances by using zinc and can contribute to the minimization of national protein need and health hazards by supplying tasty, healthy and antibiotic-free broiler meat.

\section{Acknowledgment}

The authors want to express deepest gratitude to the members of the department of Animal Science and Nutrition and Department of Genetics and Animal Breeding, Hajee Mohammad Danesh Science \& Techssnology University, Dinajpur, Bangladesh for their cordial assistance and guideline to conduct this research work. 


\section{Ethical Committee Report}

Ethical committee of Hajee Mohammad Danesh Science \& Technology University, Bangladesh reported that present study has followed all of the research ethics and did not observe any issues against the ethical rules. (Report Date-07.06.2020, Report No. HSTU/RES/EC2059)

\section{Conflict of Interest}

None of them

\section{References}

Abhishek B, Rajeev VR, Vincent BP, Xin T, Chenchen L, Keji L, Caroline AR, Zhanyan F, Rudolf J, Mriganka S. 2016. Jointly reduced inhibition and excitation underlies circuit-wide changes in cortical processing in Rett syndrome. Proceedings of the National Academy of Sciences of the United States of America. 113(46): E7287-E7296.

Bartlett JR, Smith MO. 1998. Effects of different levels of zinc on the performance and immune competence of broilers under heat stress. Poult. Sci. 82: 1580-1588.

Bertuzzi S, Manfreda G, Franchini A. 1998. Influence of dietary inorganic zinc and vitamin $\mathrm{E}$ on broiler immune response. Selezione Vet. 8(9): 627-636.

Butler E, Curtis M. 1973. The effects of Escherichia coli endotoxin and ACTH on the plasma zinc concentration in the domestic fowl. Res. in Vet. Sci. 15(3): 363-367.

Dozier WA, Davis AJ, Freeman ME, Ward TL. 2003. Early growth and environmental implications of dietary zinc and copper concentrations and sources of broiler chicks. Br. Poult. Sci., 44: 726-731.

Ezzati M, Elio RMD, Lopez AD. 2013. Behavioral and Dietary Risk Factors for Noncommunicable Diseases. N. Engl. J. Med. 369: 954-964

Fraker, Bertuzzi, 1977. The effect of protamine zinc insulin on weight gain and fat deposition in the juvenile domestic duck Quarterly J. Experimental Physiology. 57: 1-11.

Greene LW, Lunt DK, Byers FM. 1988. Performance and carcass quality of steers supplemented with zinc oxide or zinc methionine. J. Anim. Sci. 66: 1818-1823.

Hosseini-Mansoub N, Chekani-Azar S, Tehrani AA, Lotfi A, Khosravi MM. 2010. Influence of dietary vitamin $\mathrm{E}$ and zinc on performance, oxidative stability and some blood measures of broiler chickens reared under heat stress $\left(35^{\circ} \mathrm{C}\right)$. J. Agron. 2: $103-110$
Huang YL, Lu L, Luo XG, Liu, B. 2007. An optimal dietary zinc level of broiler chicks fed a corn-soybean meal diet. Poult. Sci., 86(12): 2582-2589.

Jones R. 1984. A standard method of dissection for carcass analysis of poultry. Ayr, Scotlands: West of Scotland Agricultural Research. Technical Note No. 222.

Keith AM, Chih CH, Carol AF, 2000. Function and Mechanism of Zinc Metalloenzymes. Journal Of nutrition. Volume-130, 5, 1437S-1446S.

Kibria ASMG, MA Awal, M Mostofa, AKM Saifuddin, MR Alam, Asgar MA. 2009. Detection of ciprofloxacin and enrofloxacin residues in broilers of Chittagong. International Journal of Biological Research.2: 33-35.

Lamberg, SL, Rothstein R. 1977. Laboratory manual of hematology and urinalysis. Avi. Publishing Company, Inc, West Port Connecticut, USSR.

Liu D, Guo SS, Guo YM. 2012. Xylanase supplementation to a wheat-based diet alleviated the intestinal mucosal barrier impairment of broiler chickens challenged by Clostridium perfringens. Avian Pathol. 41:291-298.

Midilli M, Salman M, Muglali OH, Ogretmen T, Cenesiz S, Ormanci N. 2014. The Effects of Organic or Inorganic Zinc and Microbial Phytase, Alone or in Combination, on the Performance, Biochemical Parameters and Nutrient Utilization of Broilers Fed a Diet Low in Available Phosphorus. World Academy of Science, Engineering and Technology. Int. J. Bio., Biomol., Agril., Food and Biotech. Engi. 8(5): 469-475.

Mohanna C. 1999. Effect of dietary zinc content and sources on the growth, body zinc deposition and retention, zinc excretion and immune response in chickens. Br. Poult. Sci., 40: 108114 .

Naz S, Idris M, Khalique M.A, Rahman Zia-ur, Alhidary IA, Abdelrahman MM, Khan RU, Chand N, Farooq U, Ahmad S. 2016. The activity and use of zinc in poultry Diets. World's Poult. Sci. J., vol. 72: 159-167

NRC. 1994. Nutrient requirements of poultry, 9th Revise. Ed, National Academy Press, Washington, DC.

Sadoval, Collins, Moran. 1999. Relative bioavailability of supplemental inorganic zinc sources for chicks. J. Anim. Sci.75: 3195-3205.

Sanford PE, Kawchumnong R. 1972. Organic chromium and zinc supplementation of broiler rations. Poult. Sci. 51(suppl. 1): 1856.

Swinkels, JWGM, Kornegay ET, Verstegen MWA. 1994. Biology of zinc and biological value of dietary organic zinc complexes and chelates. Nutr. Res. Rev. 7:129-149 